ORNLTM-13234

\section{OAK RIDEE NATIONAL IABORATORY}

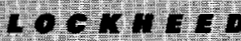

Results of Sampling the Contents of the Liquid Low-Level Waste Evaporator Feed Tank W-22 at ORNL

\author{
RECEIVED \\ OCT 181996 \\ OSTI
}

M. B. Sears 
This report has been reproduced directly from the best available copy.

Available to DOE and DOE contractors from the Office of Scientific and Technical Information, P. O. Box 62, Oak Ridge, TN 37831 ; prices available from (423) 576-8401, FTS 626-8401.

Available to the public from the National Technical Information Service, U.S. Department of Commerce, 5285 Port Royal Road. Springfield, VA 22161.

This report was prepared as an account of work sponsored by an agency of the United States Government. Neither the United States Government nor any agency thereof, nor any of their employees, makes any warranty, express or implied, or assumes any legal liability or responsibility for the accuracy, completeness, or usefulness of any information, apparatus, product, or process disclosed, or represents that its use would not infringe privately owned rights. Reference herein to any specific commercial product, process, or service by trade name, trademark, manufacturer, or otherwise, does not necessarily constitute or imply its endorsement, recommendation, or favoring by the United States Government or any agency thereof. The views and opinions of authors expressed herein do not necessarily state or reflect those of the United States Govemment of any agency thereof. 
Chemical Technology Division

\title{
RESULTS OF SAMPLING THE CONTENTS OF THE LIQUID LOW-LEVEL WASTE EVAPORATOR FEED TANK W-22 AT ORNL
}

\author{
M. B. Sears
}

Date Published-September 1996

\author{
Prepared for \\ Environmental Restoration and Waste Management-Defense \\ (Activity No. EW3120041) \\ Prepared by the \\ OAK RIDGE NATIONAL LABORATORY \\ Oak Ridge, Tennessee 37831 \\ managed by \\ LOCKHEED MARTIN ENERGY RESEARCH CORP. \\ for the \\ U.S. DEPARTMENT OF ENERGY \\ under contract DE-AC05-960R22464
}




\section{DISCLAIMER}

Portions of this document may be illegible in electronic image products. Images are produced from the best available original document. 


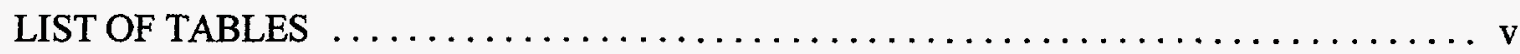

ACRONYMS $\ldots \ldots \ldots \ldots \ldots \ldots \ldots \ldots \ldots \ldots \ldots \ldots \ldots \ldots \ldots \ldots \ldots \ldots \ldots \ldots \ldots \ldots \ldots \ldots \ldots$

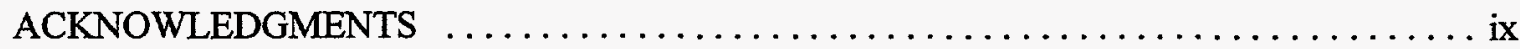

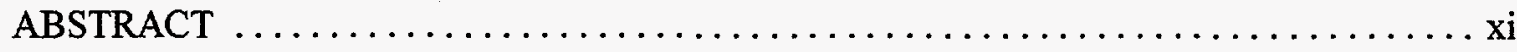

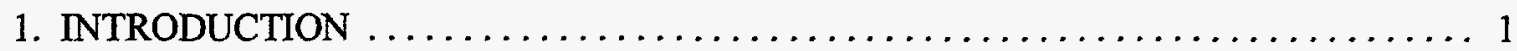

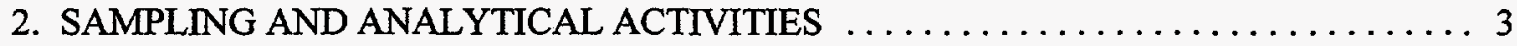

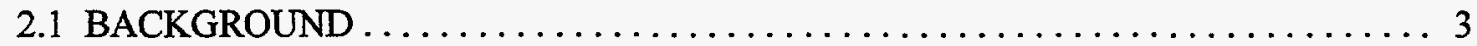

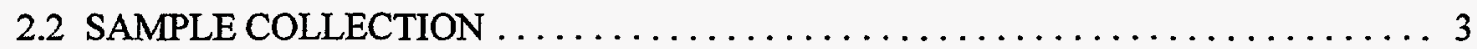

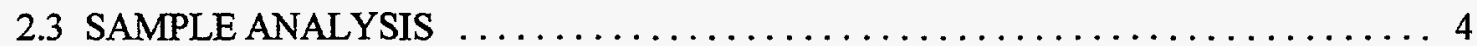

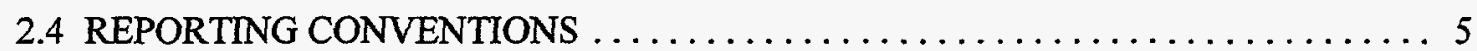

3. WASTE CHARACTERIZATION SUMMARY FOR TANK W-22 $\ldots \ldots \ldots \ldots \ldots \ldots 7$

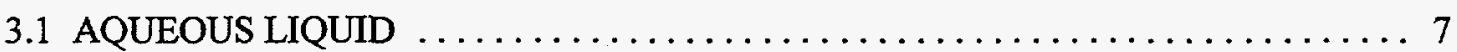

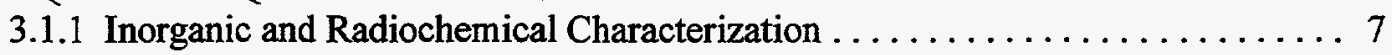

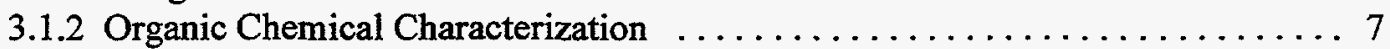

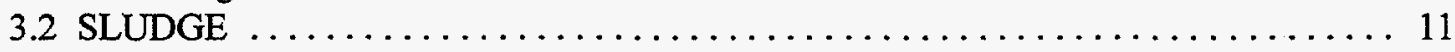

3.2.1 Inorganic and Radiochemical Characterization ................ 11

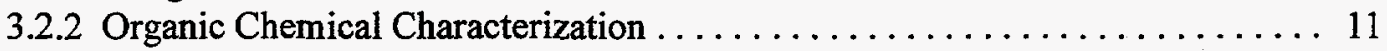

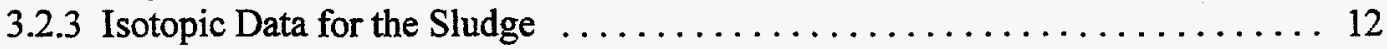

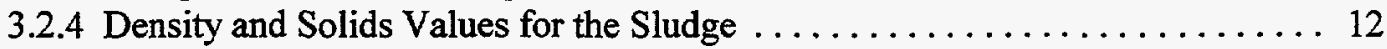

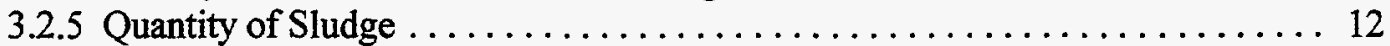

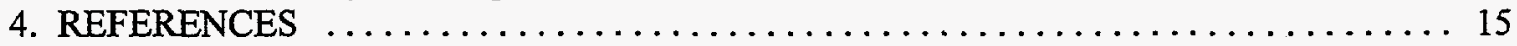

APPENDIX: TABLES PRESENTING DETAILED ANALYTICAL DATA $\ldots \ldots \ldots \ldots 17$ 


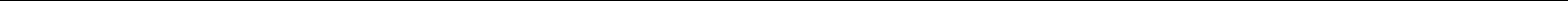




\section{LIST OF TABLES}

Table 3.1 Waste characterization data for tank $W-22 \ldots \ldots \ldots \ldots \ldots \ldots \ldots \ldots$

Table 3.2 Summary of organic characterization results for tank $W-22 \ldots \ldots \ldots \ldots \ldots$

Table 3.3 Uranium and plutonium mass spectrometry data for tank

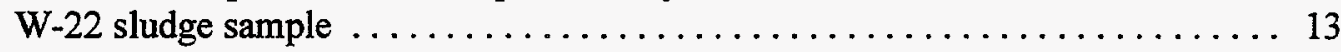

Table 3.4 Principal nuclear materials in tank $W-22$ sludge sample $\ldots \ldots \ldots \ldots \ldots \ldots \ldots$

Table 3.5 Actinide concentrations in sludge sample $\mathrm{W} 22-\mathrm{S} \ldots \ldots \ldots \ldots \ldots \ldots \ldots \ldots$

Table 3.6 Density and solids measurements for sludge sample from tank W-22 $\ldots \ldots \ldots 14$

Table A.1 Analytical data for samples from tank $W-22 \ldots \ldots \ldots \ldots \ldots \ldots \ldots \ldots$

Table A.2 Compound list and reporting limits for analyses of tank W-22 samples:

Semivolatile organic compound analyses $\ldots \ldots \ldots \ldots \ldots \ldots \ldots \ldots \ldots 22$

Table A.3 Compound list and reporting limits for analyses of tank W-22 samples:

Pesticide/PCB analyses . . . . . . . . . . . . . . . . . . . . 24

Table A.4 Compound list and reporting limits for water-soluble volatile organic

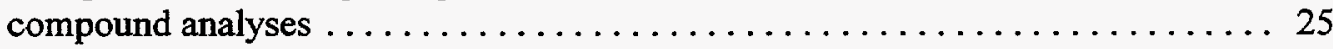





\section{ACRONYMS}

$\begin{array}{ll}\text { ASME } & \text { American Society of Mechanical Engineers } \\ \text { ASO } & \text { Analytical Services Organization } \\ \text { CASD } & \text { Chemical and Analytical Sciences Division } \\ \text { DAI-GC } & \text { Direct-aqueous-injection gas chromatography } \\ \text { EPA } & \text { U.S. Environmental Protection Agency } \\ \text { FFA } & \text { Federal Facility Agreement } \\ \text { GC-MS } & \text { Gas chromatography-mass spectrometry } \\ \text { HEPA } & \text { High-efficiency particulate air (filtration system) } \\ \text { LLW } & \text { Low-level waste } \\ \text { LLLW } & \text { Liquid low-level waste } \\ \text { MVST } & \text { Melton Valley Storage Tank } \\ \text { ORNL } & \text { Oak Ridge National Laboratory } \\ \text { PCB } & \text { Polychlorinated biphenyl } \\ \text { PVC } & \text { Polyvinyl chloride (polymer) } \\ \text { RCRA } & \text { Resource Conservation and Recovery Act } \\ \text { TCL } & \text { Target Compound List } \\ \text { TIC } & \text { Tentatively identified compound } \\ \text { TRU } & \text { Transuranic }\end{array}$




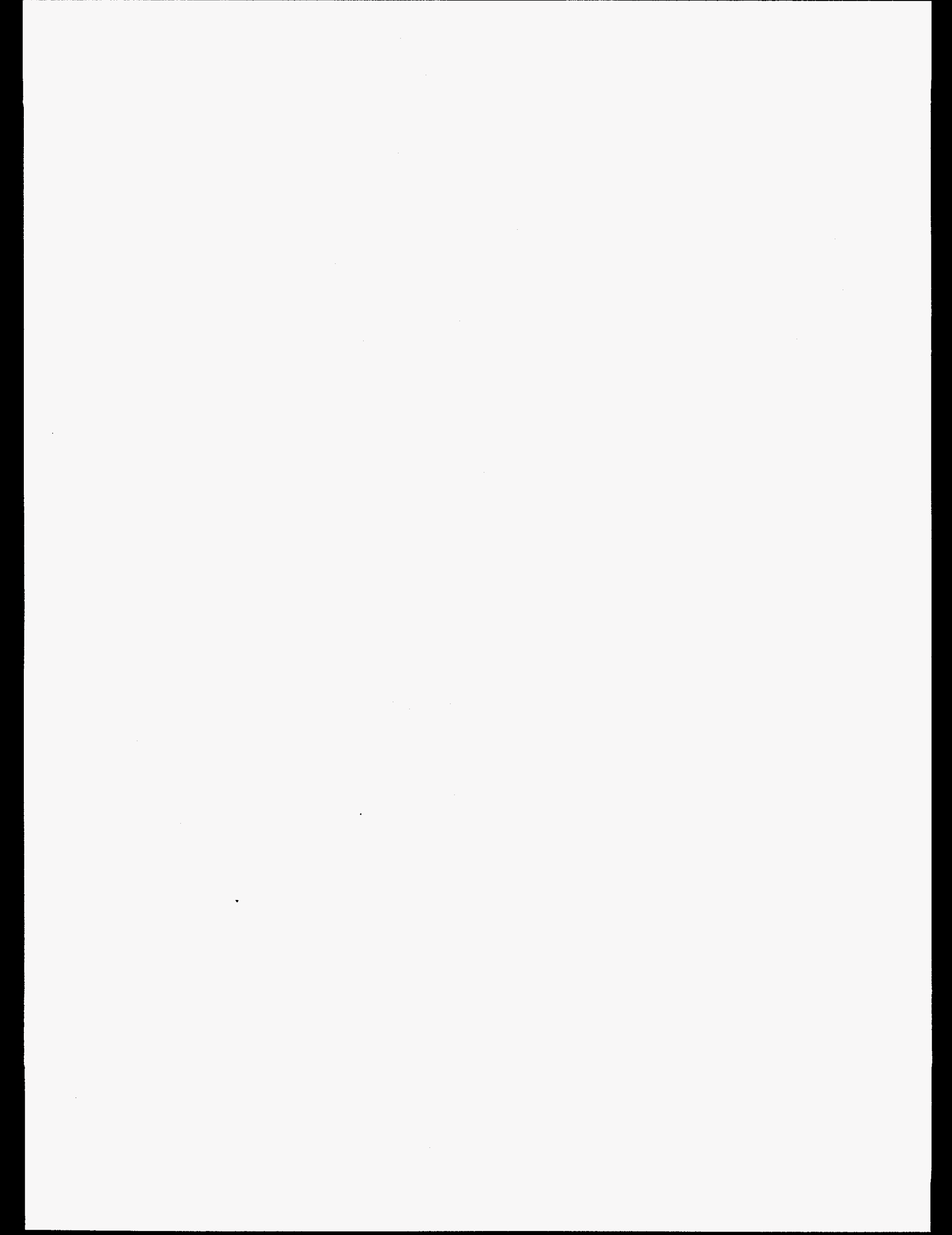




\section{ACKNOWLEDGMENTS}

This project involved the cooperation and participation of several analytical groups. Most of the analyses were performed by staff of the Chemical and Analytical Sciences Division (CASD) of the Oak Ridge National Laboratory (ORNL). The organization, preparation of the composite sludge sample, sample distribution, inorganic analyses, and most of the radiochemical analyses were performed by the CASD Radioactive Materials Analysis group. For the organic characterization, the samples were extracted in radiochemical laboratories by the CASD Analytical Methods group. The decontaminated extracts were then transferred to the nonzoned laboratories of the central Analytical Services Organization (ASO) of Lockheed Martin Energy Systems, Inc. Most quantitative measurements of organic constituents were made by the ASO. However, water-soluble volatile organic compounds were analyzed using direct-aqueous-injection gas chromatography by the CASD Analytical Methods group. Other CASD groups who contributed were the Inorganic Mass Spectrometry and Neutron Activation Analysis laboratories. The author is also indebted to staff of the Liquid and Gaseous Waste Operations Department within the ORNL Waste Management Remedial Action Division for tank-sampling services and field-sampling data. 


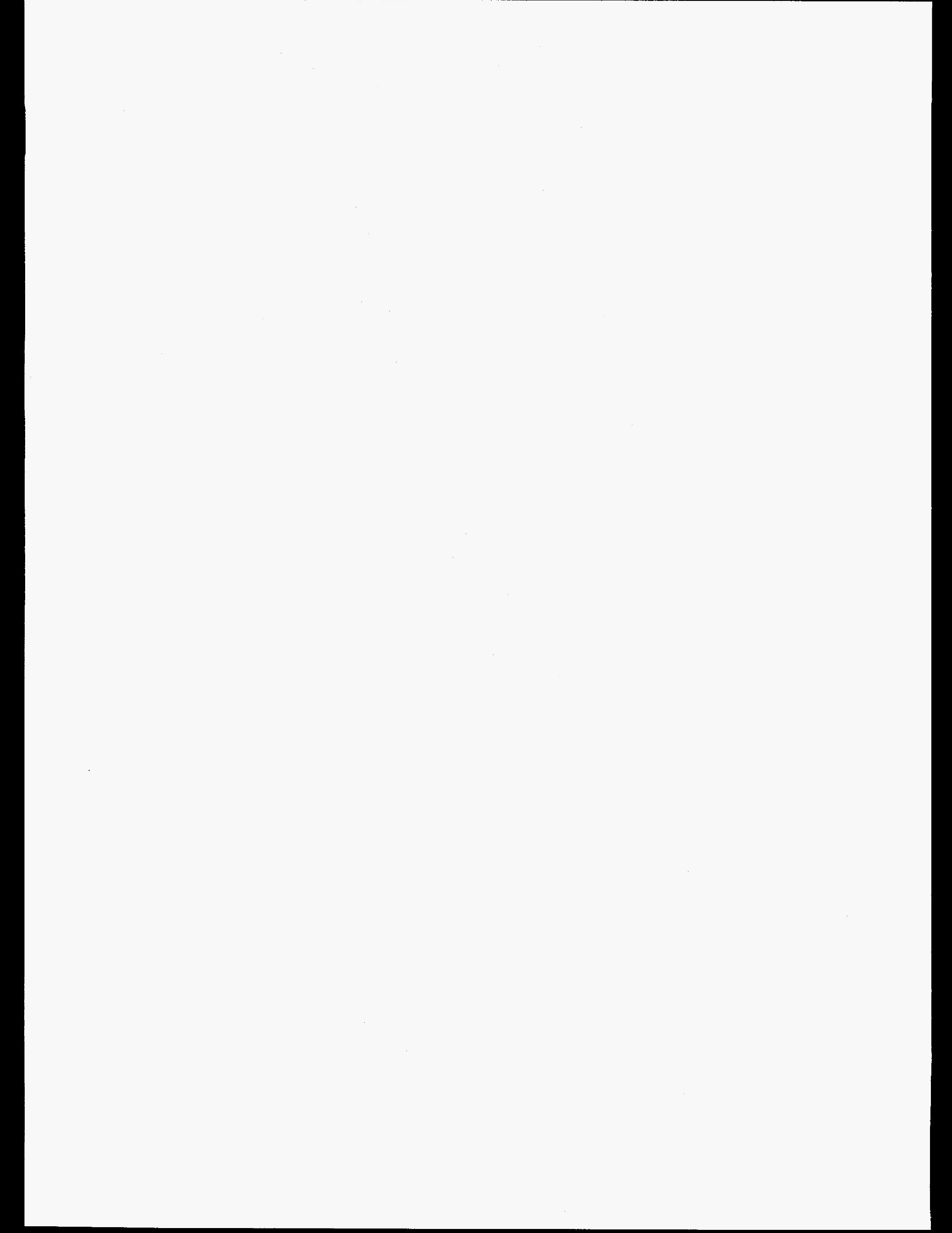




\begin{abstract}
This report summarizes the results of the fall 1994 sampling of the contents of the liquid lowlevel waste (LLLW) tank W-22 at the Oak Ridge National Laboratory (ORNL). Tank W-22 is the central collection and holding tank for LLLW at ORNL before the waste is transferred to the evaporators. Samples of the tank liquid and sludge were analyzed to determine (1) the major chemical constituents, (2) the principal radionuclides, (3) the metals listed on the U.S. Environmental Protection Agency (EPA) Contract Laboratory Program Inorganic Target Analyte List, (4) organic compounds, and (5) some physical properties. The organic chemical characterization consisted of the determinations of the EPA Contract Laboratory Program Target Compound List semivolatile compounds, pesticides, and polychlorinated biphenyls (PCBs). Water-soluble volatile organic compounds were also determined.

Information provided in this report forms part of the technical basis in support of (1) waste management for the active LLLW system and (2) planning for the treatment and disposal of the waste.
\end{abstract}




\section{INTRODUCTION}

Studies were conducted to characterize the wastes in the liquid low-level waste (LLLW) evaporator feed tank W-22 at the Oak Ridge National Laboratory (ORNL). Tank W-22, a relatively large tank $(50,000 \mathrm{gal})$, is the central collection and holding tank for LLLW before the waste is transferred to the evaporators. Objectives of the study included providing data to support (1) the Federal Facility Agreement (FFA) for the Oak Ridge Reservation, (2) the removal of the sludge from the tank and waste-treatability studies, and (3) nuclear criticality and fire safety aspects of the hazard analysis. Samples of the supernatant liquid and the sludge were analyzed to determine (1) major chemical constituents, (2) principal radionuclides, (3) hazardous constituents, (4) organic compounds, and (5) general waste characteristics.

An overview of the sampling and analytical activities is given in Sect. 2, and a summary of the waste characterization results is presented in Sect. 3. Tables with additional analytical data are provided in the appendix.

This is one of several reports on the characterization of radioactive tank wastes at ORNL. The results of the sampling and analysis of the LLLW concentrates stored in the Melton Valley Storage Tanks (MVSTs) and the evaporator facility storage tanks are reported in ref. 1 , and the characterization of residual wastes in $\sim 40$ inactive tanks is reported in refs. $2-5$. 



\section{SAMPLING AND ANALYTICAL ACTIVITIES}

\subsection{BACKGROUND}

The LLLWs generated at ORNL are collected and transferred to the evaporator facility for concentration by processing in the low-level waste (LLW) evaporators. The resulting concentrates are then stored in tanks at the MVST site and at the evaporator service facility (Building 2537) in Bethel Valley. Tank W-22 is used as the feed tank to the evaporators. Wastes are made basic before they are sent to tank W-22, which precipitates most of the transuranic (TRU) and heavy metals to the sludge phase. Solids also may be transferred to the waste system from other sources such as spent offgas scrubber solutions. Over several years of operation, sludge has accumulated in the bottom of the tank.

Tank W-22 is a 50,000-gal, horizontal, stainless steel tank. The tank, which is nominally $12 \mathrm{ft}$ in diam by $60 \mathrm{ft}$ long, is located in a below-grade, reinforced concrete vault with a stainless steel liner, which provides radiation shielding and secondary containment. Waste transfers are handled remotely. Access to the tank contents is very limited, consisting of one pipe, 3 in. in diam, that extends through the vault roof. The configuration of tank W-22 is similar to that of tanks W-21 and W-23 at the evaporator service facility and that of the MVSTs. ${ }^{1}$

The tank is equipped with air spargers and an off-gas sweep and is ventilated by a central, hot off-gas system, which is operated under a small, negative pressure relative to the atmosphere. The offgas system includes a scrubber and a high-efficiency particulate air (HEPA) filtration system. The effluent is released through the 3039 stack. Before the tank contents were sampled, the air spargers were turned "off," and the sludge solids were then allowed to settle overnight.

\subsection{SAMPLE COLLECTION}

The sampling plan provides information concerning (1) the supernatant liquid, (2) the sludge phase, and (3) the air-liquid interface. The sampling methods and equipment were essentially the same as those used in earlier sampling campaigns. ${ }^{1-5}$ A sludge-level detector was used to locate the air-liquid and the liquid-sludge interfaces, thus establishing the depth of the supernatant liquid in the tank. Samples of the supernatant liquid were collected from the midpoint of the liquid layer, $\sim 7 \mathrm{in}$. above the sludge layer. The samples were pulled by suction through Teflon ${ }^{\mathrm{TM}}$ tubing into $250-\mathrm{mL}$ glass sample jars using a small vacuum-pump sampling system. Actual sample volumes were $\sim 180-200 \mathrm{~mL}$ with $\sim 1 \mathrm{~cm}(\sim 15-25 \mathrm{~mL})$ headspace. Eight bottles of sample material were collected and processed as aliquots of one sample at the laboratory. 
The air-liquid interface was checked for the presence of an immiscible (i.e., organic) layer floating over the aqueous layer. The bottom-opening soft-sludge sampler was used to collect a "column" of liquid at the interface. The sample was pulled and examined visually in the field. The interface sample was clear with no immiscible phases. No organic layer was observed. (The interface sample was then returned to the tank.)

Two "cores" of sludge were then collected from different depths to provide "cores" representative of a vertical profile of the sludge in the tank. The soft-sludge sampling device consists of a detachable handle assembly and a hollow probe of polyvinyl chloride (PVC) pipe with a bottom closure that can be controlled from above by the operator. Because only sludge directly under the access port can be sampled, the samples may not be representative of other locations in the tank. Sludge sampling is described in more detail in ref. 1 (pp. 15-18).

Based on the field measurements, the depth of the sludge layer in tank W-22 was $\sim 2 \mathrm{ft} 4 \mathrm{in}$. at the sampling location. The distance from the top of the flange on the access pipe to the tank bottom was $18 \mathrm{ft} 6$ in.

\subsection{SAMPLE ANALYSIS}

The U.S. Environmental Protection Agency (EPA) analytical methods were followed, inasmuch as possible, in analyses for constituents listed as hazardous under the Resource Conservation and Recovery Act (RCRA) and for the organic chemical characterization. Generally modifications of methods from the EPA guide, Test Methods for Evaluating Solid Waste (SW-846), were used. ${ }^{6}$ Some modifications to the standard procedures were necessary because of the radiation levels, salt content, and generally complex chemical matrices in the samples. Methodology was modified or developed on an as-needed basis. Procedures for the other analysis were selected from the Chemical and Analytical Sciences Division methods or modified EPA methods based on the sample characteristics and type of information needed.,

Two "cores" of sludge were collected from the tank in order to have a vertical profile of the tank contents. The samplers contained both sludge and a small amount of the overlying supernatant tank liquid. At the analytical laboratory, the samples were set up and allowed to stand overnight inside the PVC sampling tubes to allow the sludge solids to settle. The phases were then separated and transferred to glass sample jars. A composite sludge sample (sample W22-S) was then made up by combining representative portions of the sludge phase from the two "cores" and mixing the portions together by sonication. The sample was divided into aliquots for the various analyses immediately after sonication. A small aliquot of the sludge interstitial liquid was also drawn off for analysis of 
water-soluble volatile organic compounds. The remaining portions of the liquid and sludge solids fractions were reserved.

Metals, radioactive materials, organic compounds, and other parameters were determined on aliquots of the sonicated sludge. The sludge sample was prepared for metal and radionuclide analyses by microwave-assisted digestion in concentrated nitric acid. The semivolatile organic analysis of the sludge was a gas chromatography-mass spectrometry (GC-MS) analysis after extraction of the organic compounds with methylene chloride.

The volatile organic compound analysis by purge and trap GC-MS was not performed because the samples were too radioactive to process in a conventional, nonzoned laboratory. However, watersoluble volatile organics were determined by direct-aqueous-injection gas chromatography (DAI-GC), which is conducted in a radiochemical laboratory. The sludge sample was not assayed for total organic carbon, total inorganic carbon, and total carbon because of problems with the instrument.

\subsection{REPORTING CONVENTIONS}

Some initialisms and other data-reporting conventions used in Sect. 3 are defined as follows:

\section{Inorganic and radiochemical characterization}

Less-than symbol, $<\quad$ Constituent was not detected, and the limit of detection or the reporting limit is reported.

$\mathrm{N}$

Qualitative analysis; $\mathrm{N}=$ not detected.

$\mathrm{Y}$

Qualitative analysis; $\mathrm{Y}=$ detected.

Parenthesis, ( )

Data in parentheses (e.g., for $\mathrm{Ag}$ ) are of questionable quality because of poor spike recovery.

\section{Organic chemical characterization}

Reporting limits

B

J

GC-MS
The reporting limits are the concentrations above which the response of the instrument for a calibrated range of concentrations is linear.

Data qualifier meaning that the compound also was found in the accompanying laboratory blank sample.

Data qualifier meaning that the compound was estimated at a concentration below the reporting limit; also used to indicate that the concentrations for tentatively identified compounds (TICs) are estimates.

Gas chromatography-mass spectrometry. 
PCB

TCL

TIC
Polychlorinated biphenyl.

Target Compound List.

Tentatively identified compound. The identification is based upon the mass spectrum only, and the quantitation is based upon the response factor of the nearest eluting internal standard. All TIC values are estimates and bear the "J" qualifier. 


\section{WASTE CHARACTERIZATION SUMMARY FOR TANK W-22}

Samples of the supernatant liquid and the sludge were analyzed to determine (1) the major chemical constituents, (2) the principal radionuclides, (3) metals listed on the EPA Contract Laboratory Program Inorganic Target Analyte List, ${ }^{8}(4)$ organic compounds, and (5) some physical properties. The organic chemical characterization consisted of determinations of the EPA Contract Laboratory Program Target Compound List (TCL) semivolatile compounds, pesticides, and polychlorinated biphenyls (PCBs). ${ }^{9}$

A summary of the waste characterization data for tank W-22 is presented in Sects 3.1 and 3.2. Only those organic compounds whose presence was indicated by the analyses are listed in the summary table. Also while RCRA and proposed RCRA (Ni and Tl) metals are included, in the case of other metal analytes, only those metals present at concentrations $\geq 1 \mathrm{mg} / \mathrm{L}$ for the liquid sample and $\geq 10 \mathrm{mg} / \mathrm{kg}$ for sludge are listed. Tables with detailed analytical data are provided in the appendix as follows: (1) a complete listing of the inorganic and radiochemical analytical data including trace metals below the cutoffs (Table A.1), and (2) the TCLs for the organic analyses (102 organic compounds) and the reporting limit for each compound (Tables A.2-A.4).

\subsection{AQUEOUS LIQUID}

\subsubsection{Inorganic and Radiochemical Characterization}

The results of the inorganic and radiochemical analyses for the liquid sample, W22-L1, are summarized in Table 3.1. The sample was radioactive with ${ }^{137} \mathrm{Cs}$, the principal contributor. Dose rates for $\sim 200 \mathrm{~mL}$ of sample in glass jars were $\sim 37 \mathrm{mrem} / \mathrm{h}$ at contact (laboratory survey). The waste was basic ( $\mathrm{pH}$ of 12.4) with sodium and nitrate the principal inorganic analytes, and the waste contained a little chloride, bromide, and sulfate. The concentrations of other inorganic analytes were relatively low. The gross alpha was $<2 \mathrm{~Bq} / \mathrm{mL}$.

\subsubsection{Organic Chemical Characterization}

The organic characterization of the liquid sample is summarized in Table 3.2. The watersoluble volatile organics analysis showed the presence of $1500 \mu \mathrm{g} / \mathrm{L}$ of methyl alcohol and $890 \mathrm{~J} \mu \mathrm{g} / \mathrm{L}$ of n-butyl alcohol. The only TCL constituent detected in the semivolatile organic compound analysis (reporting limits of 56-144 $\mu \mathrm{g} / \mathrm{L}$ ) was a trace of a phthalate below the reporting limit. No pesticides were detected (reporting limits of $0.25-5 \mu \mathrm{g} / \mathrm{L}$ ), and only a trace of a PCB which was below the reporting limit. Seven semivolatile organic tentatively identified compounds (TICs) were observed 
Table 3.1. Waste characterization data for tank W-22

\begin{tabular}{|c|c|c|}
\hline Characteristic & $\begin{array}{l}\text { W22-L1 } \\
\text { Liquid }(a)\end{array}$ & $\begin{array}{c}\text { W22-S } \\
\text { Sludge }(b)(c)\end{array}$ \\
\hline \multicolumn{3}{|l|}{ Physical properties and miscellaneous data } \\
\hline Total dissolved solids ( $\mathrm{mg} / \mathrm{mL}$ or $\mathrm{mg} / \mathrm{g}$ ) & 23.4 & 26 \\
\hline Total solids (mg/mL or $\mathrm{mg} / \mathrm{g}$ ) & 24.6 & 268 \\
\hline Density $(\mathrm{g} / \mathrm{mL})$ & 1.008 & 1.17 \\
\hline Inorganic carbon $(\mathrm{mg} / \mathrm{L})$ & $(<15)(d)$ & (e) \\
\hline Total organic carbon (mg/L) & $(98)$ & $(e)$ \\
\hline Total carbon $(\mathrm{mg} / \mathrm{L})$ & (98) & $(e)$ \\
\hline \multicolumn{3}{|l|}{ RCRA metals (mg/L or $\mathrm{mg} / \mathrm{kg})$} \\
\hline $\mathrm{Ag}$ & $(<0.006)$ & 2.0 \\
\hline As & 0.015 & $<4.4$ \\
\hline $\mathrm{Ba}$ & 0.61 & 70 \\
\hline $\mathrm{Cd}$ & $<0.008$ & 23 \\
\hline $\mathrm{Cr}$ & $<0.005$ & 146 \\
\hline $\mathrm{Hg}$ & 0.029 & 105 \\
\hline $\mathrm{Ni}$ & 0.14 & 71 \\
\hline $\mathrm{Pb}$ & $<0.42$ & 341 \\
\hline $\mathrm{Se}$ & $<0.006$ & $<4.4$ \\
\hline $\mathrm{Tl}$ & $<0.15$ & $<24$ \\
\hline \multicolumn{3}{|l|}{ Process metals (mg/L or $\mathrm{mg} / \mathrm{kg}$ ) } \\
\hline $\mathrm{Al}$ & 0.9 & 1,900 \\
\hline $\mathrm{Ca}$ & 27 & 33,600 \\
\hline $\mathrm{Cu}$ & 0.06 & 34 \\
\hline $\mathrm{Fe}$ & 0.08 & 2,150 \\
\hline $\mathrm{K}$ & 41 & 3,270 \\
\hline $\mathrm{Mg}$ & 0.03 & 3,620 \\
\hline $\mathrm{Mn}$ & $<0.01$ & 182 \\
\hline $\mathrm{Na}$ & 5,200 & 15,400 \\
\hline Th & $<0.05$ & 10,600 \\
\hline $\mathrm{U}$ & $<0.09$ & 35,500 \\
\hline $\mathrm{Zn}$ & $<0.02$ & 1,100 \\
\hline \multicolumn{3}{|l|}{ Anions (mg/L or $m g / k g)$} \\
\hline Bromide & 195 & \\
\hline Chloride & 355 & \\
\hline Cyanide & $(<0.010)$ & $(<5.4)$ \\
\hline Fluoride & 86 & \\
\hline Nitrate & 12,700 & \\
\hline Nitrite $(f)$ & $\mathrm{Y}$ & \\
\hline Phosphate & $<10$ & \\
\hline Sulfate & 119 & \\
\hline Sulfide $(f)$ & $\mathrm{N}$ & $\mathrm{N}$ \\
\hline
\end{tabular}


Table 3.1. Waste characterization data for tank W-22 (continued)

\begin{tabular}{|c|c|c|}
\hline Characteristic & $\begin{array}{l}\text { W22-L1 } \\
\text { Liquid }(a)\end{array}$ & $\begin{array}{c}\text { W22-S } \\
\text { Sludge }(b)(c)\end{array}$ \\
\hline \multicolumn{3}{|l|}{ Alkalinity } \\
\hline $\mathrm{pH}$ & 12.4 & \\
\hline $\mathrm{OH}^{-}(M)$ & 0.03 & \\
\hline $\mathrm{CO}_{3}^{2-}(M)$ & $<0.1$ & \\
\hline $\mathrm{HCO}_{3}^{-}(M)$ & $<0.1$ & \\
\hline \multicolumn{3}{|c|}{ Radiochemical screening ( $B q / m L$ or $B q / g$ ) } \\
\hline Gross alpha & $<1.9 \mathrm{E}+0$ & $1.4 \mathrm{E}+5$ \\
\hline Gross beta & $1.4 \mathrm{E}+5$ & $3.1 \mathrm{E}+6$ \\
\hline Total Pu alpha & $(g)$ & $2.4 \mathrm{E}+4$ \\
\hline \multicolumn{3}{|c|}{ Beta/gamma emitters (Bq/mL or Bq/g) } \\
\hline${ }^{60} \mathrm{Co}$ & $<1.3 \mathrm{E}+1$ & $3.1 \mathrm{E}+4$ \\
\hline${ }^{134} \mathrm{Cs}$ & $9.7 \mathrm{E}+3$ & $1.1 \mathrm{E}+4$ \\
\hline${ }^{137} \mathrm{Cs}$ & $1.0 \mathrm{E}+5$ & $4.2 \mathrm{E}+5$ \\
\hline${ }^{152} \mathrm{Eu}$ & $<1.1 \mathrm{E}+2$ & $5.6 \mathrm{E}+5$ \\
\hline${ }^{154} \mathrm{Eu}$ & $<4.9 \mathrm{E}+1$ & $2.5 \mathrm{E}+5$ \\
\hline${ }^{155} \mathrm{Eu}$ & $<1.8 \mathrm{E}+2$ & $5.8 \mathrm{E}+4$ \\
\hline${ }^{90} \mathrm{Sr}(h)$ & $3.9 \mathrm{E}+3$ & $6.2 \mathrm{E}+5$ \\
\hline${ }^{99} \mathrm{Tc}(i)$ & $2.5 \mathrm{E}+0$ & $1.7 \mathrm{E}+2$ \\
\hline \multicolumn{3}{|c|}{ Alpha emitters by alpha spectrometry ( $B q / g$ ) } \\
\hline${ }^{244} \mathrm{Cm}$ & $(g)$ & $9.5 \mathrm{E}+4$ \\
\hline${ }^{238} \mathrm{Pu} /{ }^{241} \mathrm{Am}$ & & $2.8 \mathrm{E}+4$ \\
\hline${ }^{239} \mathrm{Pu} /{ }^{240} \mathrm{Pu}$ & & $1.1 E+4$ \\
\hline${ }^{233} \mathrm{U} /{ }^{229} \mathrm{Th}$ & & $3.5 \mathrm{E}+3$ \\
\hline
\end{tabular}

(a) Sample collected August 25, 1994 from the midpoint of the liquid layer, $\sim 7 \mathrm{in}$. above the sludge layer. Analytical request number IPA7180.

(b) Sludge sample data are reported on a wet weight basis.

(c) Sample W22-S was a composite of the sludge in samples W22-S1 and W22-S2 collected August 30, 1994. Analytical request number IPA7181.

(d) Data in parenthesis are of questionable quality because of poor spike recovery.

(e) Analysis was not run because of instrument problem.

$(f)$ Qualitative analysis. $\mathrm{N}=$ not detected. $\mathrm{Y}=$ detected.

$(g)$ Gross alpha too low for alpha measurements.

(h) The term ${ }^{90} \mathrm{Sr}$ as used in this report actually refers to the total radioactive strontium (i.e., ${ }^{89} \mathrm{Sr}$ and ${ }^{90} \mathrm{Sr}$ in combination).

(i) ${ }^{99} \mathrm{Tc}$ determined by inductively coupled plasma-mass spectrometry (ICP-MS). 
Table 3.2. Summary of organic characterization results for tank W-22

\begin{tabular}{|c|c|c|}
\hline $\begin{array}{l}\text { Analysis class and } \\
\text { compound hits }(a)\end{array}$ & $\begin{array}{c}\text { W22-L1 } \\
\text { Liquid }(b)\end{array}$ & $\begin{array}{c}\text { W22-S } \\
\text { Sludge }(c),(d)\end{array}$ \\
\hline Volatile organics & $(e)$ & (e) \\
\hline \multicolumn{3}{|l|}{ Water-soluble organics $(\mu g / L)$} \\
\hline Methyl alcohol & 1,500 & $1,540(f)$ \\
\hline n-Butyl alcohol & $890 \mathrm{~J}$ & \\
\hline \multicolumn{3}{|c|}{ Semivolatile organics $(\mu g / L$ or $\mu g / k g)$} \\
\hline Naphthalene & & $260 \mathrm{~J}$ \\
\hline Phenanthrene & & $210 \mathrm{~J}$ \\
\hline Di-n-butylphthalate & $8 \mathrm{JB}$ & $4,700 \mathrm{~B}$ \\
\hline Fluoranthene & & $81 \mathrm{~J}$ \\
\hline Pyrene & & $83 \mathrm{~J}$ \\
\hline Bis(2-ethylhexyl)phthalate & & 2,000 \\
\hline \multicolumn{3}{|l|}{ Pesticides/PCBs $(\mu g / L$ or $\mu g / k g)$} \\
\hline Aroclor-1242 & $0.75 \mathrm{~J}$ & \\
\hline Aroclor-1254 & & $44 J(g)$ \\
\hline Aroclor- 1260 & & $26 \mathrm{~J}(g)$ \\
\hline \multicolumn{3}{|c|}{ Semivolatile organic TrCs $(\mu g / L$ or $\mu g / k g)(h)$} \\
\hline Unknown & $1,700 \mathrm{~J}(7)$ & $52,000 \mathrm{~J}(1)$ \\
\hline Unknown hydrocarbons & & $145,200 \mathrm{~J}(16)$ \\
\hline Benzene derivatives & & $19,700 \mathrm{~J}(3)$ \\
\hline
\end{tabular}

(a) Only compounds whose possible presence was indicated by the analysis are listed. See Appendix Tables A.2-A.4 for the target compound lists and reporting limits.

(b) Sample collected August 25, 1994. Analytical request numbers IPA7180 and SMO04122.

(c) Sludge sample data are reported on a weight basis.

(d) Sample W22-S was a composite of the sludge in samples W22-S1 and W22-S2 collected August 30, 1994. Analytical request numbers IPA7181 and SMO04200.

(e) Analysis was not run because the sample was too radioactive for nonzoned laboratory.

(f) Analysis performed on the interstitial liquid of the sludge. Units are micrograms per liter of interstitial liquid.

(g) See discussion in Sect. 3.2.2.

(h) Result is the sum of the tentatively identified compounds (TICs). The number of TICs are shown in parenthesis. 
(total, $\sim 1700 \mathrm{~J} \mu \mathrm{g} / \mathrm{L}$ ). The volatile organics analysis by GC-MS was not performed because the sample was too radioactive to process in a conventional, nonzoned laboratory. The total organic carbon was relatively low $(98 \mathrm{mg} / \mathrm{L})$.

\subsection{SLUDGE}

\subsubsection{Inorganic and Radiochemical Characterization}

The tank W-22 sludge contained relatively high levels of alpha emitters, europium isotopes, ${ }^{137} \mathrm{Cs},{ }^{90} \mathrm{Sr}$, and ${ }^{60} \mathrm{Co}$, and some metals listed as hazardous under RCRA (Table 3.1). The principal metals were uranium, thorium, calcium, and sodium. The sludge is a TRU waste containing $\sim 36,000 \mathrm{~Bq} / \mathrm{g}(\sim 970 \mathrm{nCi} / \mathrm{g})$ of alpha-emitting TRUs with half-lives greater than 20 years. Betagamma dose rates (laboratory survey) for the samples in the PVC tubes were as follows: (1) sample W22-S1, $\sim 800 \mathrm{mrem} / \mathrm{h}$ unshielded at contact for $\sim 250 \mathrm{~mL}$ of sludge and (2) sample W22-S2, $\sim 600 \mathrm{mrem} / \mathrm{h}$ for $\sim 220 \mathrm{~mL}$ of sludge. Gamma dose rates were $\sim 600$ and $\sim 450 \mathrm{mrem} / \mathrm{h}$ for W22-S1 and W22-S2, respectively.

The data for the metals and radioactive materials are for the sludge which dissolved during microwave-assisted digestion in concentrated nitric acid. A trace of residue (not analyzed) was left following the digestion.

\subsubsection{Organic Chemical Characterization}

A summary of the results for the organic characterization of the composite sludge sample W22-S is presented in Table 3.2. The TCL semivolatile organic compounds found were di-nbutylphthalate (4700B $\mu \mathrm{g} / \mathrm{kg})$ and bis(2-ethylhexyl)phthalate $(2000 \mu \mathrm{g} / \mathrm{kg})$, and traces of naphalene, phenanthrene, fluoranthene, and pyrene below the reporting limits $(740-1875 \mu \mathrm{g} / \mathrm{kg})$. The semivolatile organic TICs included 16 unknown hydrocarbons (total, $\sim 145,200 \mathrm{~J} \mu \mathrm{g} / \mathrm{kg}$ ), 1 unknown $(\sim 52,000 \mathrm{~J} \mu \mathrm{g} / \mathrm{kg}$ ), and 3 benzene derivatives (total, $\sim 19,700 \mathrm{~J} \mu \mathrm{g} / \mathrm{kg}$ ). No pesticides were observed (reporting limits of $36-716 \mu \mathrm{g} / \mathrm{kg}$ ). The PCB analysis (reporting limits of $358-716 \mu \mathrm{g} / \mathrm{kg}$ ) detected traces of Aroclor-1254 and Aroclor-1260 which were below the reporting limits. The PCB values in Table 3.2 may be a little low because the recovery of the decachlorobiphenyl internal surrogate standard was low. Results for the matrix spike sample (which was spiked not with PCBs, but only with certain pesticides) were $327 \mathrm{~J}$ and $107 \mathrm{~J} \mu \mathrm{g} / \mathrm{kg}$ for Aroclor- 1254 and Aroclor- 1260 , respectively. The PCB values for the matrix spike sample are thought to be high because there were matrix interferences with the peaks. However, the surrogate standard recovery for the matrix spike sample 
was acceptable. A conservative approach would be to assume $500 \mu \mathrm{g} / \mathrm{kg}(0.5 \mathrm{ppm})$ total PCBs in sludge sample W22-S.

Water-soluble volatile organics were determined in an interstitial liquid sample from the sludge. Methyl alcohol was found at $1540 \mu \mathrm{g} / \mathrm{L}$. The volatile organics analysis by GC-MS was not conducted because the sample was too radioactive to process in a nonzoned analytical laboratory.

\subsubsection{Isotopic Data for the Sludge}

The results of the uranium and plutonium isotopic analyses of the sludge by mass spectrometry are shown in Table 3.3 as the fraction (atom \%) of the total present, and the principal nuclear materials in the sludge (micrograms per gram of sludge) in Table 3.4. The results for the gross fissile analysis by neutron activation analysis with delayed neutron counting are in agreement with the values from the mass spectrometry data. The gross fissile content is reported as a ${ }^{235} \mathrm{U}$ equivalent, but it is actually a measure of the total fissile content. The denature ratios for uranium and plutonium $(>100)$ are in accordance with the waste acceptance criteria for wastes discharged into the LLLW system. (The denature ratio is the ratio of chemically similar nonfissile isotopes to fissile isotopes.)

A listing of the actinide concentrations (becquerels per gram of sludge) is provided in Table 3.5, which incorporates the mass spectrometry data for uranium and plutonium.

\subsubsection{Density and Solids Values for the Sludge}

The density and solids content of the whole sludge and its dissolved and undissolved components were determined by the method developed by Ceo et al. ${ }^{10}$ The results for the composite sludge sample W22-S are presented in Table 3.6. The undissolved solids component was $24.2 \mathrm{wt} \%$ with a density of $2.9 \mathrm{~g} / \mathrm{mL}$. This density, which is a little higher ( $2.9 \mathrm{vs.} 1.7-2.4 \mathrm{~g} / \mathrm{mL}$ ) than the densities reported for the undissolved solids in other waste tank sludges, is probably the result of the higher heavy metal (i.e., uranium and thorium) content of the precipitated solids (ref. 5, pp 4-30 to $4-39$, and ref. 10, p. 30 ).

\subsubsection{Quantity of Sludge}

The estimated volume of sludge in tank W-22 is 6,750 gal $(25,600 \mathrm{~L})$ based on the depth of sludge at the sampling location. The calculations assume a horizontal tank with heads which coincide with the drawing and American Society of Mechanical Engineers (ASME) norms.*

*Drawing S-20237-YB-016-E, "Evaporator Service Tanks Plan, Elevation \& Nozzle Schedule," 8/15/75. 
Table 3.3. Uranium and plutonium mass spectrometry data for tank W-22 sludge sample

\begin{tabular}{cr}
\hline Characteristic & W22-S \\
\hline & \\
Uranium isotopes (atom \% of total $U$ ) & \\
${ }^{233} \mathrm{U}$ & 0.05 \\
${ }^{234} \mathrm{U}$ & 0.01 \\
${ }^{235} \mathrm{U}$ & 0.24 \\
${ }^{236} \mathrm{U}$ & 0.01 \\
${ }^{238} \mathrm{U}$ & 99.71 \\
& \\
${ }^{2 l u t o n i u m}$ isotopes (atom \% of total Pu) & \\
${ }^{238} \mathrm{Pu}$ & 1.03 \\
${ }^{239} \mathrm{Pu}$ & 80.96 \\
${ }^{240} \mathrm{Pu}$ & 16.41 \\
${ }^{241} \mathrm{Pu}$ & 0.70 \\
${ }^{242} \mathrm{Pu}$ & 0.88 \\
${ }^{244} \mathrm{Pu}$ & 0.02 \\
\hline
\end{tabular}

Table 3.4. Principal nuclear materials in tank W-22 sludge sample

\begin{tabular}{lc}
\hline Characteristic & W22-S \\
\hline & \\
Isotopic concentration in waste $(\mu g / g)$ & 17.4 \\
${ }^{233} \mathrm{U}$ & 84.1 \\
${ }^{235} \mathrm{U}$ & 0.025 \\
${ }^{238} \mathrm{Pu}$ & 1.99 \\
${ }^{239} \mathrm{Pu}$ & 0.017 \\
${ }^{241} \mathrm{Pu}$ & \\
& \\
Gross fissile $(\mu g / g)$ & 80 \\
${ }^{235} \mathrm{U}$ equivalent $($ a $)$ & \\
${ }^{\text {Denature ratio }}$ & \\
${ }^{238} \mathrm{U} /{ }^{235} \mathrm{U}$ fissile equivalent $(b)$ & 329 \\
${ }^{232} \mathrm{Th} /\left({ }^{239} \mathrm{Pu}+{ }^{241} \mathrm{Pu}\right)$ & 5270 \\
\hline
\end{tabular}

(a) The gross fissile data are based upon neutron activation followed by delayed neutron counting. The equivalent values are relative to known ${ }^{235} \mathrm{U}$ standards.

$(b){ }^{235} U$ fissile equivalent mass $=\left[\left(1.35 x^{233} U\right)+{ }^{235} U\right]$. 
Table 3.5. Actinide concentrations in sludge sample W22-S

\begin{tabular}{llcc}
\hline Isotope & $\begin{array}{c}\text { Decay } \\
\text { mode }\end{array}$ & $\begin{array}{c}\text { Concentration } \\
(\mathrm{Bq} / \mathrm{g})\end{array}$ & Comment \\
\hline${ }^{241} \mathrm{Am}$ & Alpha & $1.2 \mathrm{E}+4$ & $($ a $)$ \\
${ }^{244} \mathrm{Cm}$ & Alpha & $9.5 \mathrm{E}+4$ & $($ a $)$ \\
${ }^{238} \mathrm{Pu}$ & Alpha & $1.6 \mathrm{E}+4$ & $(b)$ \\
${ }^{239} \mathrm{Pu}$ & Alpha & $4.6 \mathrm{E}+3$ & $(b)$ \\
${ }^{240} \mathrm{Pu}$ & Alpha & $3.4 \mathrm{E}+3$ & $(b)$ \\
${ }^{241} \mathrm{Pu}$ & Beta & $6.6 \mathrm{E}+4$ & $(b)$ \\
${ }^{242} \mathrm{Pu}$ & Alpha & $3.0 \mathrm{E}+0$ & $(b)$ \\
${ }^{232} \mathrm{Th}$ & Alpha & $4.4 \mathrm{E}+1$ & $(c)$ \\
${ }^{233} \mathrm{U}$ & Alpha & $6.1 \mathrm{E}+3$ & $($ d $)$ \\
${ }^{234} \mathrm{U}$ & Alpha & $7.9 \mathrm{E}+2$ & $($ d $)$ \\
${ }^{235} \mathrm{U}$ & Alpha & $6.6 \mathrm{E}+0$ & $($ d $)$ \\
${ }^{238} \mathrm{U}$ & Alpha & $4.5 \mathrm{E}+2$ & $($ d $)$ \\
\hline
\end{tabular}

(a) By alpha spectrometry.

(b) By mass spectrometry; total plutonium alpha by a radiochemical method.

(c) Assumes thorium $>99.9 \mathrm{wt} \%{ }^{232} \mathrm{Th}$; total thorium by inductively coupled plasma (ICP).

(d) By mass spectrometry; total uranium by ICP.

Table 3.6. Density and solids measurements for sludge sample from tank W-22

\begin{tabular}{lc}
\hline \multicolumn{1}{c}{ Property } & $\begin{array}{c}\text { W-22-S } \\
\text { Sludge }(a)\end{array}$ \\
\hline Sludge solids $(w t \%)$ & \\
Total solids & 26.8 \\
Dissolved solids & 2.6 \\
Undissolved solids & 24.2 \\
& \\
Density $(g / m L)$ & \\
Bulk sludge & 1.17 \\
Interstitial liquid & 0.98 \\
Undissolved solids & 2.91 \\
\hline
\end{tabular}

(a) Sample W22-S was a composite of the sludge in samples W22-S1 and W22-S2. 


\section{REFERENCES}

1. M. B. Sears et al., Sampling and Analysis of Radioactive Liquid Wastes and Sludges in the Melton Valley and Evaporator Facility Storage Tanks at ORNL, ORNL/TM-11652, Martin Marietta Energy Systems, Inc., Oak Ridge National Laboratory, Oak Ridge, Tennessee, September 1990.

2. J. W. Autrey et al., Sampling and Analysis of the Inactive Waste Storage Tank Contents at ORNL, ORNL/ER-13, Martin Marietta Energy Systems, Inc., Oak Ridge National Laboratory, Oak Ridge, Tennessee, September 1990.

3. J. W. Autrey et al., Sampling and Analysis of the Inactive Waste Tanks TH-2, WC-1, and WC-15, ORNL/ER-19, Martin Marietta Energy Systems, Inc., Oak Ridge National Laboratory, Oak Ridge, Tennessee, February 1992.

4. Results of Fall 1994 Sampling of Gunite and Associated Tanks at the Oak Ridge National Laboratory, Oak Ridge, Tennessee, ORNL/ER/Sub/87-99053/74, Lockheed Martin Energy Systems, Inc., Oak Ridge National Laboratory, Oak Ridge, Tennessee, June 1995.

5. M. B. Sears et al., Sampling and Analysis of Inactive Radioactive Waste Tanks W-17, W-18, WC-5, WC-6, WC-8 and WC-11 Through WC-14 at ORNL, Lockheed Martin Energy Systems, Inc., Oak Ridge National Laboratory, Oak Ridge, Tennessee, December 1995.

6. U.S. Environmental Protection Agency, Test Methods for Evaluating Solid Waste, SW-846, 3rd ed., Office of Solid Waste and Emergency Response, Washington, D.C., November 1986; and Updates, September 1994.

7. U.S. Environmental Protection Agency, Methods for Chemical Analysis of Water and Wastes, EPA-600/4-79-020, Rev., Environmental Monitoring and Support Laboratory, Office of Research and Development, U.S. Environmental Protection Agency, Cincinnati, Ohio, March 1983.

8. U.S. Environmental Protection Agency Contract Laboratory Program, "Statement of Work for Inorganics Analysis, Multi-Media, Multi-Concentration," SOW No. 787, 1987.

9. U.S. Environmental Protection Agency Contract Laboratory Program, "Statement of Work for Organic Analysis, Multi-Media, Multi-Concentration," Document Number OLM01.0 and Revisions OLM01.1-OLM01.9 (July 1993).

10. R. N. Ceo, M. B. Sears, and J. T. Shor, Physical Characterization of Radioactive Sludges in Selected Melton Valley and Evaporator Facility Storage Tanks, ORNL/TM-11653, Martin Marietta Energy Systems, Inc., Oak Ridge National Laboratory, Oak Ridge, Tennessee, October 1990. 

Appendix

TABLES PRESENTING DETAILED ANALYTICAL DATA 

Table A.1. Analytical data for samples from tank W-22

\begin{tabular}{|c|c|c|c|c|}
\hline \multirow[t]{2}{*}{ Parameter measured } & \multicolumn{2}{|c|}{$\begin{array}{l}\text { W22-L1 } \\
\text { Liquid }(a)\end{array}$} & \multicolumn{2}{|c|}{$\begin{array}{c}\text { W22-S } \\
\text { Sludge }(b),(c)\end{array}$} \\
\hline & Result & $+1-$ & Result & $+/-$ \\
\hline \multicolumn{5}{|c|}{ Physical properties and miscellaneous data } \\
\hline Total solids $(\mathrm{mg} / \mathrm{mL}$ or $\mathrm{mg} / \mathrm{g})$ & 24.6 & & 268 & \\
\hline Dissolved solids ( $\mathrm{mg} / \mathrm{mL}$ or $\mathrm{mg} / \mathrm{g}$ ) & 23.4 & & 25.5 & \\
\hline Undissolved solids (mg/mL or $\mathrm{mg} / \mathrm{g}$ ) & & & 242 & \\
\hline Liquid density ( $\mathrm{g} / \mathrm{mL}$ ) & 1.008 & 0.018 & 0.980 & \\
\hline Bulk sludge density $(\mathrm{g} / \mathrm{mL})$ & & & 1.17 & \\
\hline Floc density $(\mathrm{g} / \mathrm{mL})$ & & & 2.91 & \\
\hline Inorganic carbon $(\mathrm{mg} / \mathrm{L})$ & $(<15)(d)$ & & (e) & \\
\hline Total organic carbon (mg/L) & (98) & 15 & (e) & \\
\hline Total carbon (mg/L) & (98) & 10 & $(e)$ & \\
\hline \multicolumn{5}{|l|}{$R C R A$ metals $(m g / L$ or $m g / k g)$} \\
\hline Arsenic & 0.015 & 0.001 & $<4.4$ & \\
\hline Barium & 0.606 & 0.006 & 70.1 & 0.3 \\
\hline Cadmium & $<0.008$ & & 22.9 & 2.5 \\
\hline Chromium & $<0.005$ & & 146 & 1.0 \\
\hline Lead & $<0.42$ & & 341 & 31 \\
\hline Mercury & 0.029 & 0.010 & 105 & 18 \\
\hline Nickel & 0.135 & 0.016 & 70.9 & 3.2 \\
\hline Selenium & $<0.006$ & & $<4.4$ & \\
\hline Silver & $(<0.006)$ & & 2.03 & 0.96 \\
\hline Thallium & $<0.15$ & & $<24$ & \\
\hline \multicolumn{5}{|l|}{ Process metals ( $\mathrm{mg} / \mathrm{L}$ or $\mathrm{mg} / \mathrm{kg}$ ) } \\
\hline Aluminum & 0.943 & 0.014 & 1,900 & 25 \\
\hline Antimony & $<0.16$ & & $<26$ & \\
\hline Beryllium & $<0.001$ & & 2.59 & 0.08 \\
\hline Calcium & 26.6 & 0.4 & 33,600 & 130 \\
\hline Cobalt & $<0.009$ & & 2.6 & 3.3 \\
\hline Copper & 0.064 & 0.002 & 33.7 & 0.4 \\
\hline Iron & 0.075 & 0.008 & 2,150 & 5 \\
\hline Magnesium & 0.026 & 0.015 & 3,620 & 25 \\
\hline Manganese & $<0.001$ & & 182 & 0.1 \\
\hline Potassium & 40.9 & 0.4 & 3,270 & 32 \\
\hline Sodium & 5,190 & 155 & 15,400 & 550 \\
\hline Technetium $(f)$ & 0.004 & & 0.272 & \\
\hline Thorium & $<0.050$ & & 10,600 & 210 \\
\hline Uranium & $<0.088$ & & 35,500 & 1,200 \\
\hline Vanadium & $<0.025$ & & $<4.0$ & \\
\hline Zinc & $<0.025$ & & 1,100 & 11 \\
\hline
\end{tabular}


Table A.1. Analytical data for samples from tank W-22 (continued)

\begin{tabular}{|c|c|c|c|c|}
\hline \multirow[t]{2}{*}{ Parameter measured } & \multicolumn{2}{|c|}{$\begin{array}{l}\text { W22-L1 } \\
\text { Liquid (a) }\end{array}$} & \multicolumn{2}{|c|}{$\begin{array}{c}\text { W22-S } \\
\text { Sludge }(b),(c)\end{array}$} \\
\hline & Result & $+1-$ & Result & $+1-$ \\
\hline \multicolumn{5}{|l|}{ Anions (mg/L or $m g / k g)$} \\
\hline Bromide & 195 & 3 & & \\
\hline Chloride & 355 & 1 & & \\
\hline Cyanide & $(<0.010)$ & & $(<5.4)$ & \\
\hline Fluoride & 86 & 1 & & \\
\hline Nitrate & 12,700 & 100 & & \\
\hline Nitrite $(g)$ & $\mathrm{Y}$ & & & \\
\hline Phosphate & $<10$ & & & \\
\hline Sulfate & 119 & 18 & & \\
\hline Sulfide $(g)$ & $\mathrm{N}$ & & $\mathrm{N}$ & \\
\hline \multicolumn{5}{|l|}{ Alkalinity } \\
\hline $\mathrm{pH}$ & 12.39 & & & \\
\hline Hydroxide $(M)$ & 0.03 & & & \\
\hline Carbonate $(M)$ & $<0.1$ & & & \\
\hline Bicarbonate $(M)$ & $<0.1$ & & & \\
\hline \multicolumn{5}{|c|}{ Radiochemical screening (Bq/mL or $B q / g)$} \\
\hline Gross alpha & $<1.9 \mathrm{E}+0$ & & $1.4 \mathrm{E}+5$ & $0.1 E+5$ \\
\hline Gross beta & $1.4 \mathrm{E}+5$ & $0.1 \mathrm{E}+5$ & $3.1 \mathrm{E}+6$ & $0.1 \mathrm{E}+6$ \\
\hline Total Pu alpha & (h) & & $2.4 \mathrm{E}+4$ & $0.1 \mathrm{E}+4$ \\
\hline \multicolumn{5}{|c|}{ Beta/gamma emitters $(B q / m L$ or $B q / g)$} \\
\hline Co-60 & $<1.3 \mathrm{E}+1$ & & $3.1 \mathrm{E}+4$ & $0.1 \mathrm{E}+4$ \\
\hline Cs-134 & $9.7 \mathrm{E}+3$ & $0.3 E+3$ & $1.1 \mathrm{E}+4$ & $0.1 \mathrm{E}+4$ \\
\hline Cs-137 & $1.0 \mathrm{E}+5$ & $0.1 \mathrm{E}+5$ & $4.2 E+5$ & $0.1 \mathrm{E}+5$ \\
\hline Eu-152 & $<1.1 \mathrm{E}+2$ & & $5.6 \mathrm{E}+5$ & $0.2 E+5$ \\
\hline Eu-154 & $<4.9 \mathrm{E}+1$ & & $2.5 \mathrm{E}+5$ & $0.1 E+5$ \\
\hline Eu-155 & $<1.8 \mathrm{E}+2$ & & $5.8 \mathrm{E}+4$ & $0.3 \mathrm{E}+4$ \\
\hline $\operatorname{Sr}-90(i)$ & $3.9 E+3$ & $0.1 \mathrm{E}+3$ & $6.2 \mathrm{E}+5$ & $0.1 \mathrm{E}+5$ \\
\hline \multicolumn{5}{|c|}{ Alpha emitters (by alpha spectrometry) (Bq/mL or $B q / g$ ) } \\
\hline $\mathrm{Cm}-244$ & $(h)$ & & $9.5 \mathrm{E}+4$ & \\
\hline $\mathrm{Pu}-238 / \mathrm{Am}-241$ & & & $2.8 \mathrm{E}+4$ & \\
\hline $\mathrm{Pu}-239 / \mathrm{Pu}-240$ & & & $1.1 \mathrm{E}+4$ & \\
\hline U-233/Th-229 & & & $3.5 \mathrm{E}+3$ & \\
\hline \multicolumn{5}{|c|}{ Gross fissile screening $(\mu \mathrm{g} / \mathrm{mL}$ or $\mu \mathrm{g} / \mathrm{g})$} \\
\hline U-235 equivalent & 0.002 & 0.001 & 79.7 & 0.3 \\
\hline \multicolumn{5}{|c|}{ Uranium isotopes (by mass spectrometry) (atom \%) } \\
\hline U-233 & & & 0.05 & 0.01 \\
\hline U-234 & & & $<0.01$ & \\
\hline U-235 & & & 0.24 & 0.01 \\
\hline U-236 & & & $<0.01$ & \\
\hline $\mathrm{U}-238$ & & & 99.71 & 0.01 \\
\hline
\end{tabular}


Table A.1. Analytical data for samples from tank W-22 (continued)

\begin{tabular}{|c|c|c|c|c|}
\hline \multirow[t]{2}{*}{ Parameter measured } & \multicolumn{2}{|c|}{$\begin{array}{l}\text { W22-L1 } \\
\text { Liquid (a) }\end{array}$} & \multicolumn{2}{|c|}{$\begin{array}{c}\text { W22-S } \\
\text { Sludge }(b),(c)\end{array}$} \\
\hline & Result & $+1-$ & Result & $+1-$ \\
\hline \multicolumn{5}{|c|}{ Plutonium isotopes (by mass spectrometry) (atom \%) } \\
\hline $\mathrm{Pu}-238$ & & & 1.03 & 0.001 \\
\hline $\mathrm{Pu}-239$ & & & 80.96 & 0.08 \\
\hline Pu-240 & & & 16.41 & 0.05 \\
\hline $\mathrm{Pu}-241$ & & & 0.70 & 0.02 \\
\hline $\mathrm{Pu}-242$ & & & 0.88 & 0.01 \\
\hline $\mathrm{Pu}-244$ & & & 0.02 & 0.002 \\
\hline
\end{tabular}

(a) Sample collected August 25, 1994. Analytical request number IPA7180; sample number 940825-122.

(b) Sludge sample data are reported on a wet weight basis.

(c) Sample W22-S was a composite of the sludge in samples W22-S1 and W22-S2 collected August 30, 1994. Analytical request number IPA7181; sample number $940831-139$.

(d) Data in parenthesis are of questionable quality because of poor spike recovery.

(e) Analysis was not run because of instrument problem.

(f) Tc-99 determined by inductively coupled plasma-mass spectrometry (ICP-MS).

(g) Qualitative analysis. $\mathrm{N}=$ not detected. $\mathrm{Y}=$ detected.

(h) Gross alpha too low for alpha measurements.

(i) The term Sr-90 as used in this report actually refers to the total radioactive strontium (i.e., Sr-89 and Sr-90 in combination). 
Table A.2. Compound list and reporting limits for analyses of tank W-22 samples: Semivolatile organic compound analyses

\begin{tabular}{|c|c|c|}
\hline \multirow[b]{2}{*}{ Compound } & \multicolumn{2}{|c|}{ Reporting limits } \\
\hline & $\begin{array}{c}\text { Aqueous sample, } \\
\text { 200-mL aliquot } \\
(\mu \mathrm{g} / \mathrm{L})\end{array}$ & $\begin{array}{c}\text { Solid sample, } \\
13.4-\mathrm{g} \text { aliquot } \\
(\mu \mathrm{g} / \mathrm{kg})\end{array}$ \\
\hline Phenol & 56 & 740 \\
\hline bis(2-Chloroethyl)ether & 56 & 740 \\
\hline 2-Chlorophenol & 56 & 740 \\
\hline 1,3-Dichlorobenzene & 56 & 740 \\
\hline 1,4-Dichlorobenzene & 56 & 740 \\
\hline Benzyl alcohol & 56 & 740 \\
\hline 1,2-Dichlorobenzene & 56 & 740 \\
\hline 2-Methylphenol & 56 & 740 \\
\hline bis(2-Chloroisopropyl)ether & 56 & 740 \\
\hline 4-Methylphenol & 56 & 740 \\
\hline N-Nitroso-di-n-propylamine & 56 & 740 \\
\hline Hexachloroethane & 56 & 740 \\
\hline Nitrobenzene & 56 & 740 \\
\hline Isophorone & 56 & 740 \\
\hline 2-Nitrophenol & 56 & 740 \\
\hline 2,4-Dimethylphenol & 56 & 740 \\
\hline Carbazole & 56 & 740 \\
\hline bis(2-Chloroethoxy)methane & 56 & 740 \\
\hline 2,4-Dichlorophenol & 56 & 740 \\
\hline 1,2,4-Trichlorobenzene & 56 & 740 \\
\hline Naphthalene & 56 & 740 \\
\hline 4-Chloroaniline & 56 & 740 \\
\hline Hexachlorobutadiene & 56 & 740 \\
\hline 4-Chloro-3-methylphenol & 56 & 740 \\
\hline 2-Methylnaphthalene & 56 & 740 \\
\hline Hexachlorocyclopentadiene & 56 & 740 \\
\hline 2,4,6-Trichlorophenol & 56 & 740 \\
\hline 2,4,5-Trichlorophenol & 144 & 1875 \\
\hline 2-Chloronaphthalene & 56 & 740 \\
\hline 2-Nitroaniline & 144 & 1875 \\
\hline Dimethylphthalate & 56 & 740 \\
\hline Acenaphthylene & 56 & 740 \\
\hline 2,6-Dinitrotoluene & 56 & 740 \\
\hline 3-Nitroaniline & 144 & 1875 \\
\hline Acenaphthene & 56 & 740 \\
\hline 2,4-Dinitrophenol & 144 & 1875 \\
\hline 4-Nitrophenol & 144 & 1875 \\
\hline
\end{tabular}


Table A.2. Compound list and reporting limits for analyses of tank W-22 samples: Semivolatile organic compound analyses (continued)

\begin{tabular}{|c|c|c|}
\hline \multirow[b]{2}{*}{ Compound } & \multicolumn{2}{|c|}{ Reporting limits } \\
\hline & $\begin{array}{l}\text { Aqueous sample, } \\
200-\mathrm{mL} \text { aliquot } \\
(\mu \mathrm{g} / \mathrm{L})\end{array}$ & $\begin{array}{l}\text { Solid sample, } \\
\text { 13.4-g aliquot } \\
(\mu \mathrm{g} / \mathrm{kg})\end{array}$ \\
\hline Dibenzofuran & 56 & 740 \\
\hline 2,4-Dinitrotoluene & 56 & 740 \\
\hline Diethylphthalate & 56 & 740 \\
\hline 4-Chlorophenyl-phenylether & 56 & 740 \\
\hline Fluorene & 56 & 740 \\
\hline 4-Nitroaniline & 144 & 1875 \\
\hline 4,6-Dinitro-2-methylphenol & 144 & 1875 \\
\hline N-Nitrosodiphenylamine & 56 & 740 \\
\hline 4-Bromophenyl-phenylether & 56 & 740 \\
\hline Hexachlorobenzene & 56 & 740 \\
\hline Pentachlorophenol & 144 & 1875 \\
\hline Phenanthrene & 56 & 740 \\
\hline Anthracene & 56 & 740 \\
\hline Di-n-butylphthalate & 56 & 740 \\
\hline Fluoranthene & 56 & 740 \\
\hline Pyrene & 56 & 740 \\
\hline Butylbenzylphthalate & 56 & 740 \\
\hline 3,3'-Dichlorobenzidine & 56 & 740 \\
\hline Benzo(a)anthracene & 56 & 740 \\
\hline Chrysene & 56 & 740 \\
\hline bis(2-Ethylhexyl)phthalate & 56 & 740 \\
\hline Di-n-octylphthalate & 56 & 740 \\
\hline Benzo(b)fluoranthene & 56 & 740 \\
\hline Benzo(k)fluoranthene & 56 & 740 \\
\hline Benzo(a)pyrene & 56 & 740 \\
\hline Indeno( $(1,2,3-$ cd)pyrene & 56 & 740 \\
\hline $\operatorname{Dibenz}(\mathrm{a}, \mathrm{h})$ anthracene & 56 & 740 \\
\hline Benzo(g,h,i)perylene & 56 & 740 \\
\hline
\end{tabular}


Table A.3. Compound list and reporting limits for analyses of tank W-22 samples: Pesticide/PCB analyses

\begin{tabular}{|c|c|c|}
\hline \multirow[b]{2}{*}{ Compound } & \multicolumn{2}{|c|}{ Reporting limits } \\
\hline & $\begin{array}{l}\text { Aqueous sample, } \\
200 \text {-mL aliquot } \\
(\mu \mathrm{g} / \mathrm{L})\end{array}$ & $\begin{array}{c}\text { Solid sample, } \\
13.4-\mathrm{g} \text { aliquot } \\
(\mu \mathrm{g} / \mathrm{kg})\end{array}$ \\
\hline Alpha-BHC & 0.25 & 36 \\
\hline Beta-BHC & 0.25 & 36 \\
\hline Delta-BHC & 0.25 & 36 \\
\hline Gamma-BHC (Lindane) & 0.25 & 36 \\
\hline Heptachlor & 0.25 & 36 \\
\hline Aldrin & 0.25 & 36 \\
\hline Heptachlor epoxide & 0.25 & 36 \\
\hline Endosulfan I & 0.25 & 36 \\
\hline Dieldrin & 0.50 & 72 \\
\hline $4,4^{\prime}-\mathrm{DDE}$ & 0.50 & 72 \\
\hline Endrin & 0.50 & 72 \\
\hline Endosulfan II & 0.50 & 72 \\
\hline 4,4'-DDD & 0.50 & 72 \\
\hline Endosulfan sulfate & 0.50 & 72 \\
\hline 4,4'-DDT & 0.50 & 72 \\
\hline Methoxychlor & 2.5 & 358 \\
\hline Endrin ketone & 0.50 & 72 \\
\hline Alpha chlordane & 2.5 & 358 \\
\hline Gamma chlordane & 2.5 & 358 \\
\hline Toxaphene & 5.0 & 716 \\
\hline Aroclor-1016 & 2.5 & 358 \\
\hline Aroclor-1221 & 2.5 & 358 \\
\hline Aroclor- 1232 & 2.5 & 358 \\
\hline Aroclor- 1242 & 2.5 & 358 \\
\hline Aroclor-1248 & 2.5 & 358 \\
\hline Aroclor- 1254 & 5.0 & 716 \\
\hline Aroclor-1260 & 5.0 & 716 \\
\hline Endrin aldehyde & 0.50 & 72 \\
\hline
\end{tabular}


Table A.4. Compound list and reporting limits for water-soluble volatile organic compound analyses

\begin{tabular}{lc}
\hline \multicolumn{1}{c}{ Compound } & $\begin{array}{c}\text { Reporting limits for liquid } \\
\text { sample, } 3-\mu \mathrm{L} \text { aliquot } \\
(\mu \mathrm{g} / \mathrm{L})\end{array}$ \\
\hline Methyl alcohol & 1000 \\
Ethyl alcohol & 1000 \\
Acetone & 1000 \\
i-Propyl alcohol & 1000 \\
Allyl alcohol & 1000 \\
Methylethyl ketone & 1000 \\
i-Butyl alcohol & 1000 \\
n-Butyl alcohol & 1000 \\
Methyl-i-butyl ketone & 1000 \\
\hline
\end{tabular}





\section{INTERNAL DISTRIBUTION}

1. J. M. Begovich

2. E. D. Collins

3. A. G. Croff

4. S. M. DePaoli

5. J. M. Giaquinto

6. W. H. Griest

$7 . \quad$ F. J. Homan

8. T. D. Hylton

9. R. T. Jubin

10. J. M. Keller

11. T. E. Kent

12. J. J. Maddox

13. L. E. McNeese

14. T. H. Monk

15. J. W. Moore

16. B. D. Patton

17. J. H. Platfoot

18. D. E. Reichle

19. S. M. Robinson

20. T. F. Scanlan

21. C. B. Scott

22. C. A. Schrof

23-27. M. B. Sears

28. J. R. Stokely

29. L. M. Toth

30. J. R. Trabalka

31. M. J. Welch

32. Y-12 Technical Library, Document Reference Center

33-34. Central Research Library

35-36. ORNL Laboratory Records

37. ORNL Laboratory Records-RC

38. ORNL Patent Section

\section{EXTERNAL DISTRIBUTION}

39. G. L. Riner, Department of Energy, Oak Ridge Operations, P.O. Box 2001, Oak Ridge, TN 37831 .

40-41. Office of Scientific and Technical Information, P.O. Box 62, Oak Ridge, TN 37831. 